\title{
Proglacial lake sediment records reveal Holocene climate changes in the Venezuelan Andes
}

\author{
Nathan D. Stansell ${ }^{\mathrm{a}, *}$, Pratigya J. Polissar ${ }^{\mathrm{b}}$, Mark B. Abbott ${ }^{\mathrm{c}}$, Maximiliano Bezada ${ }^{\mathrm{d}}$, \\ Byron A. Steinman ${ }^{\mathrm{e}}$, Carsten Braun ${ }^{\mathrm{f}}$ \\ a Department of Geology and Environmental Geosciences, Northern Illinois University, 312 Davis Hall, Normal Road, DeKalb, IL 60115, USA \\ ${ }^{\mathrm{b}}$ Lamont-Doherty Earth Observatory of Columbia University, 61 Route 9W, Palisades, NY 10964, USA \\ ${ }^{\mathrm{c}}$ Department of Geology and Planetary Science, University of Pittsburgh, 4107 O'Hara Street, Pittsburgh, PA 15260, USA \\ ${ }^{\mathrm{d}}$ Departamento de Ciencias de la Tierra, Universidad Pedagógica Experimental Libertador, Av. Páez, El Paraíso, Caracas 1021, Venezuela \\ ${ }^{\mathrm{e}}$ Department of Meteorology and Earth and Environmental Systems Institute, Pennsylvania State University, 528 Walker Building, University Park, PA \\ 16802-5013, USA \\ ${ }^{\mathrm{f}}$ Department of Geography and Regional Planning, Westfield State University, Westfield, MA 01086, USA
}

\section{A R T I C L E I N F O}

\section{Article history:}

Received 6 November 2013

Received in revised form

24 January 2014

Accepted 28 January 2014

Available online

Keywords:

Paleoclimate

Northern tropics

Clastic sediment flux

Middle Holocene

Little Ice Age

\begin{abstract}
A B S T R A C T
Lake sediment records from the Cordillera de Mérida in the northern Venezuelan Andes document the history of local glacial variability and climate changes during the Holocene ( $\sim 12$ ka to the present). The valleys that contain these lakes have similar bedrock compositions and hypsometries, but have different headwall elevations and aspects, which makes them useful for investigating the magnitude of past glaciations. There was widespread glacial retreat in the Venezuelan Andes during the early Holocene, after which most watersheds remained ice free, and thus far only valleys with headwalls higher than $\sim 4400 \mathrm{~m}$ asl contain evidence of glaciation during the last $\sim 10 \mathrm{ka}$. There was a pronounced shift in sediment composition for the Montos (headwall: $\sim 4750 \mathrm{~m}$ asl) and Los Anteojos (headwall: $\sim 4400 \mathrm{~m}$ asl) records during the middle Holocene from $\sim 8.0$ to $7.7 \mathrm{ka}$ when conditions appear to have become ice free and drier. There is tentative evidence that the glacier in the Mucubaji valley (headwall: $\sim 4609 \mathrm{~m}$ asl) advanced from $\sim 8.1$ to $6.6 \mathrm{ka}$ and then retreated during the latter stages of the middle Holocene. Clastic sediment accumulation in other nearby lake basins was either low or decreased throughout most of the middle Holocene as watersheds stabilized under warmer and/or drier conditions. In the Montos record, there was another major shift in sediment composition that occurred from $\sim 6.5$ to $5.7 \mathrm{ka}$, similar to other regional records that suggest conditions were drier during this period. Overall, the late Holocene was a period of warmer and wetter conditions with ice extent at a minimum in the northern tropical Andes. There were also punctuated decadal to multi-centennial periods of higher clastic sediment accumulation during the last $\sim 4 \mathrm{ka}$, likely in response to periods of cooling and/or local precipitation changes. In watersheds with headwalls above $4600 \mathrm{~m}$ asl, there is evidence of glacial advances during the Little Ice Age $(\sim 0.6-0.1 \mathrm{ka})$. The pattern of glacial variability is generally similar in both the northern and southern tropics during the Little Ice Age, suggesting that ice margins in both regions were responding to colder and wetter conditions during the latest Holocene. The observed pattern of Holocene climate variability in the Venezuelan Andes cannot be explained by insolation forcing alone, and tropical ocean influences were likely associated with the observed glacial and lake level changes.
\end{abstract}

(c) 2014 Elsevier Ltd. All rights reserved.

\footnotetext{
* Corresponding author.

E-mail addresses: nstansell@niu.edu, nstansell@gmail.com (N.D. Stansell).
}

\section{Introduction}

The response of tropical climate systems to shifting boundary conditions and short-term perturbations is a central question of earth-systems science. Millennial-scale insolation changes likely drove the broad pattern of Holocene climatic changes identified by proxy records from both the northern and southern Andes (e.g. 
Abbott et al., 1997; Koch and Clague, 2006). Superimposed upon the millennial-scale trends are century-scale variations, (most notably glacial and lake-level fluctuations) driven by regional-scale temperature and precipitation changes that are not directly controlled by orbital processes (e.g. Seltzer et al., 2000; Polissar et al., 2013). For example, a clastic-rich sediment profile from the Laguna Mucubají watershed (Fig. 1) illustrates that multiple Holocene glacial advances occurred in Venezuela (Stansell et al., 2005; Polissar et al., 2006b). It remains unknown, however, if the timing of changes observed at Mucubají is representative of glacial advances in the region, or how the timing of the multi-centennial glacial advances and retreats compares to that of other tropical Andean locations. Given the range of headwall elevations and different geomorphic conditions for valleys that were potentially glaciated, there should be detectable variability in the timing of sedimentological changes in lakes between watersheds in the Venezuelan Andes. These differences, in turn, should provide information about the magnitude and timing of distinct glacial events.

Here we present three independently dated lake sediment records from different watersheds in the northern tropical Cordillera de Mérida of the Venezuelan Andes in order to evaluate the timing and extent of glaciations in each valley. These valleys have similar bedrock compositions and hypsometries, but different headwall elevations that span $\sim 350 \mathrm{~m}$ across what is thought to be a critical elevation threshold in the Venezuelan Andes (Montos $4750 \mathrm{~m}$ asl, Mucubaji $4609 \mathrm{~m}$ asl, and Anteojos $4400 \mathrm{~m}$ asl). This allows for comparison of the timing of shifting sediment characteristics across a vertical gradient. We applied a multi-proxy approach to characterize changes in fine-grained clastic (non-biogenic) sediment concentrations to infer past changes in glacial activity. We also analyzed indicators of past changes in lake productivity, including biogenic silica and organic matter, and incorporated lake level records from nearby sites into our analysis as corroborating evidence of past climate changes. Combined, these archives indicate considerable glacial and lake level variability occurred during the early, middle and late Holocene that must be influenced by forcing mechanisms other than insolation alone.

\section{Study site and modern climate}

Today in the Venezuelan Andes the majority of precipitation falls during boreal summer, and humidity is high year-round

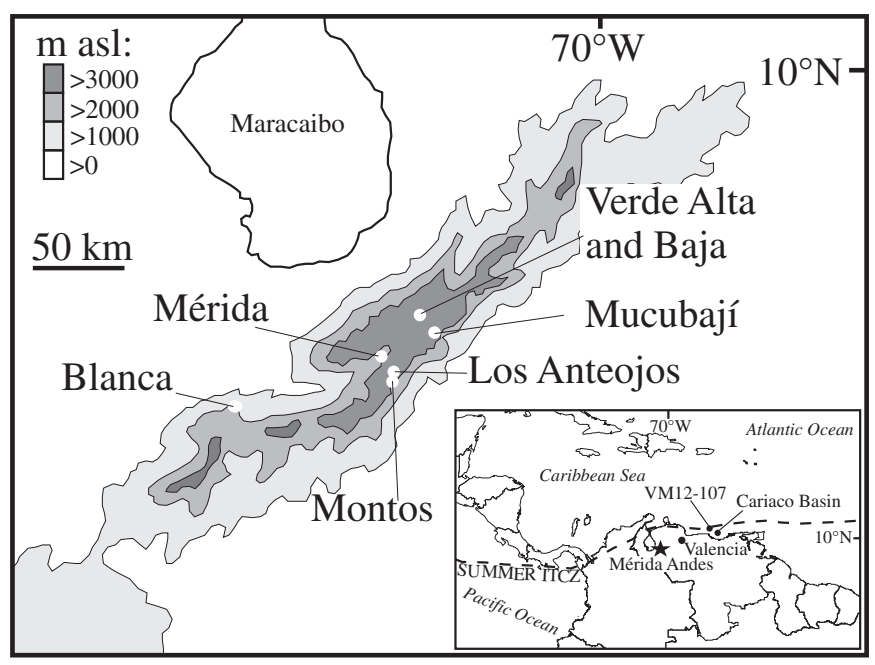

Fig. 1. Map identifying the location of Mérida Andes, and the locations of other paleoclimate records discussed in this manuscript.
(Azocar and Monasterio, 1980). Precipitation originates mostly from the Atlantic Ocean and is transported over the continent by the easterlies (Garreaud et al., 2009). The amount of precipitation that falls in Venezuela is affected by sea surface temperatures (SSTs) in both the Atlantic and Pacific Oceans; tropical North Atlantic SSTs are positively correlated, and tropical Pacific SSTs are negatively correlated with Andean rainfall (Pulwarty et al., 1992; Polissar et al., 2013). Likewise, temperature variability in the northern tropics is driven by changes in both the tropical Pacific and Atlantic Oceans (Vuille et al., 2000). The relationships between tropical ocean conditions and Andean climate change are further detailed in the discussion section below.

The wet and generally cloudy conditions make glaciers in this part of the Andes more sensitive to temperature than to precipitation changes (Kaser and Osmaston, 2002; Stansell et al., 2007b). In A.D. 1952 only four glaciated peaks remained in Venezuela, with elevations of $4979 \mathrm{~m}$ asl (Pico Bolívar), $4922 \mathrm{~m}$ asl (Pico La Concha), $4942 \mathrm{~m}$ asl (Pico Humboldt) and $4883 \mathrm{~m}$ asl (Pico Bonpland) (Schubert, 1998). Today, the only watersheds with remaining ice are Pico Humboldt and Pico Bolivar, and it is projected that all glaciers will melt in the Venezuelan Andes within the next few decades (Braun and Bezada, 2013). These catchments, however, were extensively glaciated in the past; thus lake basins in these valleys preserve evidence of shifting ice margins during at least the last $\sim 12,000$ years (Stansell et al., 2005; Polissar et al., 2006b).

\subsection{Laguna de Montos}

Laguna de Montos (N 8.512 $, \mathrm{W} 71.086^{\circ}, 4050 \mathrm{~m}$ asl) has a headwall elevation of $\sim 4750 \mathrm{~m}$ asl and is located in the Cordillera de Mérida on the southeast-facing side of the valley below the peaks of El Toro and El Leon (Fig. 2). The catchment is currently ice free, and the overflowing lake was $12.7 \mathrm{~m}$ deep in February, 2011. Glaciers do not exist in the watershed today, but ice on the flanks of El Toro (4728 $\mathrm{m}$ asl) was up to $16 \mathrm{~m}$ thick in A.D. 1868 (Jahn, 1925; Schubert, 1992). Ice existed below El Leon ( $4750 \mathrm{~m}$ asl) until A.D. 1910 (Jahn, 1925), and below El Toro until A.D. 1931 (Schubert, 1992). Meteorological data are not available for the Montos valley, but precipitation amounts are likely similar to that described below for Laguna de Los Anteojos ( $1550 \mathrm{~mm} / \mathrm{yr})$. The Montos catchment contains a well-defined cirque basin surrounded by a steep, bowl-shaped depression that keeps the lake protected from wind mixing. The protected conditions, combined with the relatively large depth for the basin size, result in a depositional environment with minimal lake sediment mixing. There is no well-established direct inflow to the lake, and it is fed mostly by on-lake precipitation and secondary surface runoff (and presumably groundwater inflow) from the catchment. The catchment bedrock is predominantly high grade meta-sedimentary rocks that are high in silicate minerals (Schubert, 1972; Hackley et al., 2005). There are prominent moraines below the lake and, although less pronounced, there are also moraines and polished bedrock glacial landforms in the watershed above the lake (Schubert, 1987). The vegetation is limited mostly to small shrubs and grasses, typical of the super páramo plant types common to the region (Berg and Suchi, 2001).

\subsection{Laguna de Los Anteojos}

The valley that contains Laguna de Los Anteojos ( $\mathrm{N} 8.538^{\circ}, \mathrm{W}$ $71.074^{\circ}, 3920 \mathrm{~m}$ asl) has a headwall elevation of $4400 \mathrm{~m}$ asl and is adjacent to Pico Espejo and the Pico Bolivar Massif (Fig. 2). Weather stations in the region have operated intermittently since at least the 1980 's, and indicate that precipitation in the area around Los Anteojos is high (1550 mm/yr) (Monasterio and Reyes, 1980; Rull 


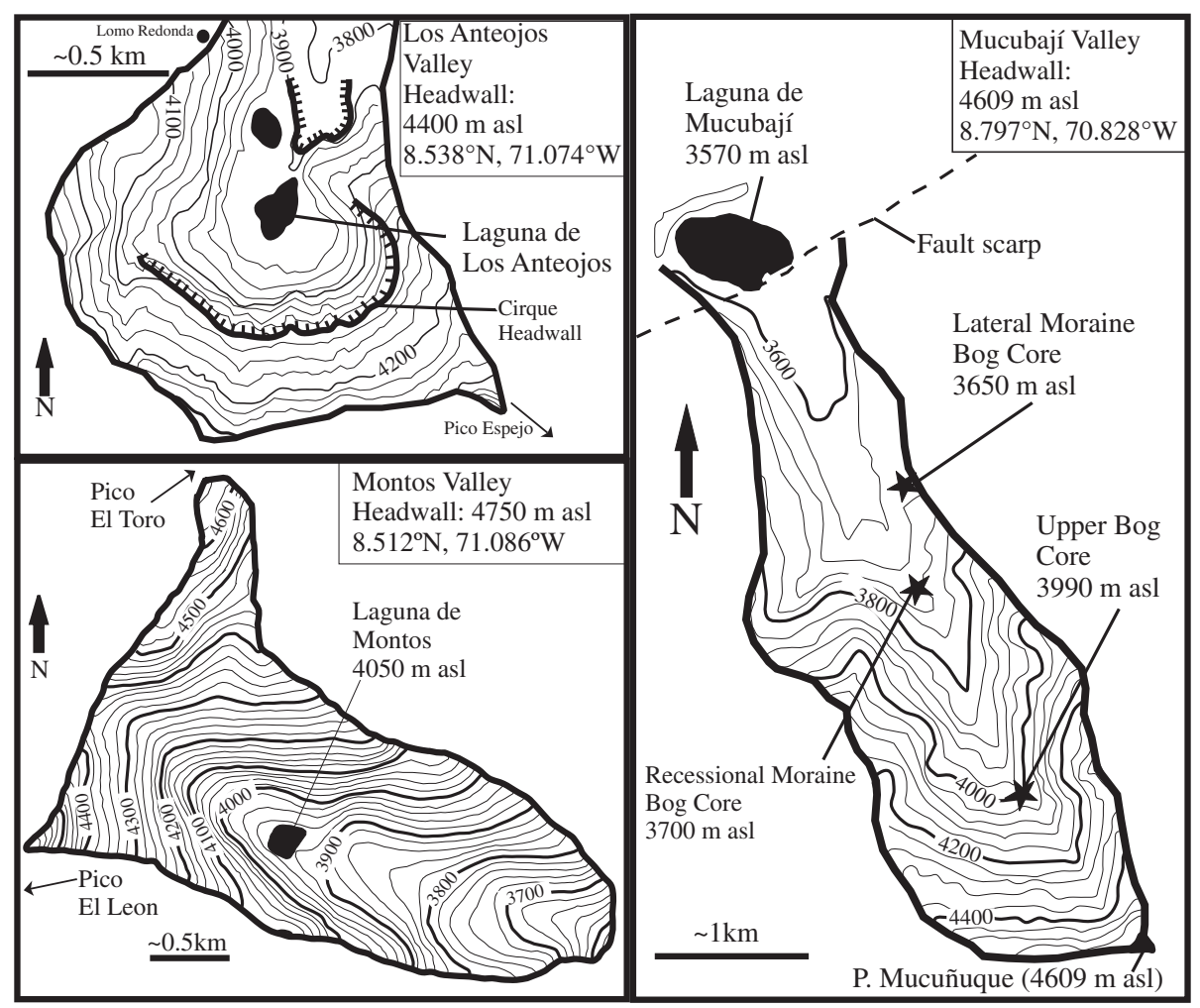

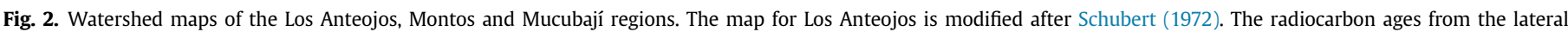

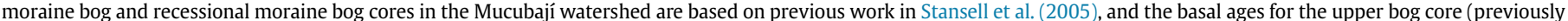
unpublished data) are in Table 1. The fault scarp trace for the Mucubají watershed is after Audemard et al. (1999).

et al., 2010). The Los Anteojos catchment is currently ice-free, as glaciers in the area are retreating rapidly and are now restricted to elevations above $\sim 4700 \mathrm{~m}$ (Schubert, 1998). The lake is relatively small $\left(\sim 0.04 \mathrm{~km}^{2}\right)$ and deep $(\sim 9 \mathrm{~m})$ with a steep $\sim 1 \mathrm{~km}^{2}$ catchment set in a north/northeast-facing cirque basin (Schubert, 1972). The underlying lithology is similar to that found in the Montos catchment with high-grade metasedimentary bedrock. There is no well-established direct inflow to the lake, and it is fed mostly by onlake precipitation and secondary runoff from rainfall in the catchment. The bathymetry of the lake is well defined, with a single bowl-shaped basin surrounded by broad, shallow ( $\sim 1 \mathrm{~m}$ deep) shelves (Rull et al., 2010; Stansell et al., 2010). The steep walls of the basin protect the lake from wind mixing, and the substantial water depth creates a low oxygen environment and minimizes bioturbation of the sediments. There are no clearly identifiable moraines on the steep terrain at elevations above the lake in the Los Anteojos valley (Schubert, 1984). Similar to the Montos watershed, the vegetation consists mostly of small shrubs and grasses, with the majority of the watershed surface consisting of exposed bedrock.

\subsection{Laguna de Mucubají}

Northeast facing Laguna de Mucubají (N 8.797 , W 70.828 ${ }^{\circ}$, $3577 \mathrm{~m}$ asl) has a headwall elevation of $4609 \mathrm{~m}$ asl and is part of the Pico Mucuñuque Massif, located in the southern range of the Cordillera de Mérida (Figs. 1 and 2). The lake is at a low elevation relative to the headwall, in comparison to the other sites in this study. This allows the lake to remain ice-free when glacial ice occupies substantial higher elevation portions of the catchment (Stansell et al., 2005). Quebrada Mucubají flows from the headwall into the lake and contributes the majority of the lake's water input (Salgado-Labouriau et al., 1992). Average annual precipitation is $\sim 980 \mathrm{~mm} /$ year (Bradley et al., 1991), and the lake is $\sim 16 \mathrm{~m}$ deep.
There are also a series of waterfalls, bedrock steps and bogs at higher elevations in the watershed. The bedrock consists mostly of high-grade metasedimentary rocks, similar to that of the Los Anteojos and Montos catchments. Active faulting in the area offsets moraines upvalley from the lake (Schubert and Sifontes, 1970; Audemard et al., 1999). Vegetation varies in the watershed and consists primarily of super páramo plant types at high elevations, and a mix of páramo and non-native plant types at lower elevations along the margins of the lake.

\section{Methods}

\subsection{Retrieval of sediment cores}

\subsubsection{Laguna de Montos}

In February, 2011, we collected a series of overlapping sediment cores from the same location at the depocenter of Montos $(\sim 13 \mathrm{~m})$ using a raft and multiple percussion and piston coring systems. The top $20 \mathrm{~cm}$ of one surface piston core (46 cm, total length) was extruded in the field at $0.25 \mathrm{~cm}$ intervals into Whirl-Pak bags. The entirety of the second surface piston core $(152 \mathrm{~cm}$, total length) was kept intact. Overlapping percussion cores totaling $394 \mathrm{~cm}$ in length were transported to the Quaternary Laboratory at the Byrd Polar Research Center for further processing.

\subsubsection{Laguna de Los Anteojos}

In January, 2007, we collected a continuous $425-\mathrm{cm}$ long percussion piston core in a single polycarbonate tube from the depocenter ( $\sim 9 \mathrm{~m})$ of Los Anteojos. A surface percussion core was also collected from the same location and extruded in the field at $0.5 \mathrm{~cm}$ intervals to capture the sediment-water interface, and to collect the uppermost $30 \mathrm{~cm}$ of flocculent material that was not recovered in the percussion core. The total sediment thickness is $455 \mathrm{~cm}$ for 
the composite Lateglacial stage and Holocene sections. The percussion core was cut into $1.5 \mathrm{~m}$ sections in the field, and all samples were transported to the Sediment Geochemistry Laboratory at the University of Pittsburgh.

\subsubsection{Laguna de Mucubají valley}

Stansell et al. (2005) and Polissar et al. (2006b) describe the coring methods used to collect sediments from Laguna de Mucubají, and nearby lateral and recessional moraine bogs that we include in this study. The lake sediment record is based on a composite of overlapping piston and surface cores collected from the same depocenter ( $16 \mathrm{~m}$ ) location. In 2007 we also recovered a $3.5 \mathrm{~m}$ sediment core from a bog on the surface of the uppermost terrace (3990 $\mathrm{m}$ asl) of the watershed using a square-rod piston corer (Fig. 2). These sediments were stored in split PVC tubes in the field and transported to the Sedimentology Laboratory at the University of Pittsburgh.

\subsection{Sediment chronology and age models}

The sediment samples used for dating were wet sieved through a $63 \mu \mathrm{m}$ screen, and macrofossils from the $>63 \mu \mathrm{m}$ subsection were picked using metal tweezers and a dissecting microscope. There is no calcareous rock in any of the Venezuelan watersheds in this study, and soils are weakly developed, which limits the input of aged carbon from the catchment. Radiocarbon samples were pretreated following established acid-base-acid procedures (Abbott and Stafford, 1996). The samples were combusted, reduced to graphite and measured (see Table 1 for facility details). The radiocarbon ages were calibrated and converted to calendar years before present (cal yr BP) using the Bayesian methods of the OxCal depositional model and the IntCal 09 dataset (Reimer et al., 2009) (present defined as A.D. 1950). The model-calibrated ages used here are the maximum likelihood values exported by OxCal (Table 1). Age-depth models (Fig. 3) were constructed using polynomial functions between the modeled radiocarbon age values.

\subsection{Sedimentology and geochemistry}

Dry bulk density (BD) was measured on $1 \mathrm{~cm}^{3}$ samples collected every 1-5 cm down-core. The samples were weighed wet and again after drying in a $60{ }^{\circ} \mathrm{C}$ oven for $24 \mathrm{~h}$. Total organic matter was measured every $1-5 \mathrm{~cm}$ by loss-on-ignition (LOI) at $550{ }^{\circ} \mathrm{C}$ (Dean Jr., 1974). LOI calculations made after heating at $1000^{\circ} \mathrm{C}$ indicate no

Table 1

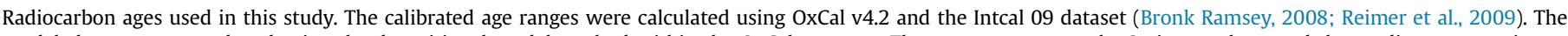

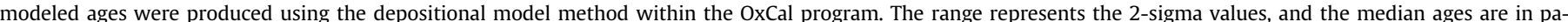

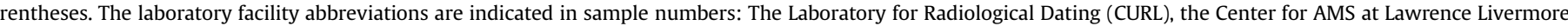
National Laboratory (CAMS), the University of Arizona AMS Facility (AA), and the University of California, Irvine, W.M. Keck Carbon Cycle AMS Laboratory (UCI).

\begin{tabular}{|c|c|c|c|c|c|c|}
\hline Location & Lab\# & Depth $(\mathrm{cm})$ & Measured ${ }^{14} \mathrm{C}$ age & Measured error $( \pm)$ & $2 \sigma$ calibrated age (cal yr BP) & Oxcal modeled age (cal yr BP) \\
\hline \multirow[t]{16}{*}{ Montos } & UCI-101244 & 8.75 & 395 & 25 & $429-(475)-510$ & $330-(477)-512$ \\
\hline & UCI-101389 & 18.75 & 605 & 15 & $583-(604)-649$ & $549-(604)-650$ \\
\hline & UCI-101245 & 28.75 & 905 & 35 & 741-(832)-913 & 740-(832)-915 \\
\hline & UCI-101507 & 38.75 & 1275 & 15 & $1178-(1228)-1269$ & $1177-(1228)-1270$ \\
\hline & UCI-101246 & 48.75 & 1550 & 25 & $1383-(1460)-1521$ & 1382-(1455)-1521 \\
\hline & UCI-101390 & 68.75 & 2225 & 15 & $2156-(2221)-2267$ & $2156-(2220)-2326$ \\
\hline & UCI-101247 & 88.75 & 2740 & 25 & $2771-(2824)-2879$ & $2770-(2825)-2918$ \\
\hline & UCI-101506 & 108.75 & 3490 & 15 & $3704-(3766)-3829$ & $3704-(3765)-3830$ \\
\hline & UCI-101248 & 128.75 & 4130 & 25 & $4567-(4673)-4728$ & $4535-(4680)-4820$ \\
\hline & UCI-101391 & 138.75 & 4760 & 15 & 5498-(5527)-5560 & 5469-(5527)-5585 \\
\hline & UCI-101249 & 147.75 & 5040 & 80 & 5609-(5788)-5922 & 5606-(5749)-5902 \\
\hline & UCI- 101508 & 167.75 & 5265 & 45 & 5929-(6052)-6129 & 5939-(6078)-6183 \\
\hline & UCI-101307 & 187.75 & 6440 & 20 & $7320-(7368)-7422$ & 7319-(7368)-7423 \\
\hline & UCI-101337 & 207.75 & 7460 & 50 & 8185-(8279)-8373 & $8187-(8285)-8367$ \\
\hline & UCI-101308 & 217.75 & 8450 & 70 & 9368-(9466)-9542 & 9301-(9462)-9542 \\
\hline & UCI-101509 & 248.50 & 9830 & 110 & 11066-(11269)-11709 & $10785-(11247)-11697$ \\
\hline \multirow[t]{12}{*}{ Anteojos } & UCI-37622 & 43.50 & 1240 & 20 & $1081-(1201)-1264$ & $1085-(1205)-1264$ \\
\hline & UCI-37535 & 65.50 & 1905 & 20 & 1817-(1852)-1897 & 1816-(1852)-1898 \\
\hline & UCI-37508 & 85.50 & 2270 & 15 & $2183-(2320)-2344$ & $2183-(2320)-2344$ \\
\hline & UCI-37510 & 148.50 & 3620 & 15 & $3876-(3929)-3980$ & $3877-(3930)-3980$ \\
\hline & UCI-37536 & 207.50 & 4915 & 25 & $5594-(5632)-5710$ & $5594-(5632)-5710$ \\
\hline & UCI-37537 & 261.60 & 6420 & 20 & $7291-(7365)-7421$ & 7293-(7365)-7422 \\
\hline & UCI-37511 & 325.60 & 8850 & 20 & $9780-(10012)-10153$ & $9780-(10015)-10153$ \\
\hline & UCI-37538 & 371.60 & 10180 & 25 & 11758-(11887)-12015 & $11758-(11885)-12006$ \\
\hline & UCI-37539 & 406.10 & 11060 & 30 & $12755-(12958)-13100$ & $12769-(12970)-13103$ \\
\hline & UCI-37540 & 425.10 & 11880 & 35 & $13507-(13742)-13871$ & $13507-(13740)-13867$ \\
\hline & UCI-37623 & 446.10 & 12430 & 80 & 14113-(14519)-15017 & 14081-(14417)-14931 \\
\hline & UCI-37509* & 113.50 & 1020 & 15 & *Not used in age model & \\
\hline \multirow[t]{13}{*}{ Mucubají } & AA-35204 & 54.19 & 635 & 45 & $547-(604)-668$ & $547-(607)-670$ \\
\hline & CURL-4959 & 67.80 & 1180 & 30 & 986-(1107)-1179 & $1001-(1117)-1231$ \\
\hline & CAMS-96810 & 72.50 & 1365 & 35 & 1185-(1291)-1345 & $1182-(1290)-1340$ \\
\hline & CURL-4960 & 94.42 & 2110 & 35 & $1992-(2082)-2295$ & $1992-(2083)-2295$ \\
\hline & AA-35205 & 113.46 & 2640 & 45 & $2715-(2763)-2853$ & $2716-(2765)-2853$ \\
\hline & CURL-4961 & 117.57 & 3100 & 45 & $3212-(3322)-3441$ & $3167-(3306)-3403$ \\
\hline & AA-35206 & 143.71 & 3665 & 80 & 3729-(3999)-4239 & $3782-(4037)-4291$ \\
\hline & CURL-4979 & 152.17 & 4060 & 60 & $4418-(4564)-4815$ & $4415-(4545)-4813$ \\
\hline & AA-35207 & 173.89 & 4640 & 110 & $4980-(5357)-5593$ & $5065-(5409)-5600$ \\
\hline & CURL-4963 & 181.95 & 4880 & 45 & 5485-(5621)-5722 & $5485-(5620)-5720$ \\
\hline & CAMS-96811 & 194.20 & 5455 & 40 & $6184-(6251)-6314$ & $6184-(6247)-6313$ \\
\hline & CAMS-96812 & 224.81 & 6620 & 200 & 7158-(7507)-7933 & $7160-(7498)-7863$ \\
\hline & CAMS-96813 & 247.68 & 7380 & 100 & $8010-(8201)-8381$ & 8008-(8195)-8380 \\
\hline \multirow[t]{2}{*}{ Mucubají upper terrace bog } & UCI-37512 & 126.00 & 8055 & 20 & 8977-(9001)-9024 & \\
\hline & UCI-37513 & 130.00 & 8140 & 20 & $9014-(9066)-9124$ & \\
\hline
\end{tabular}



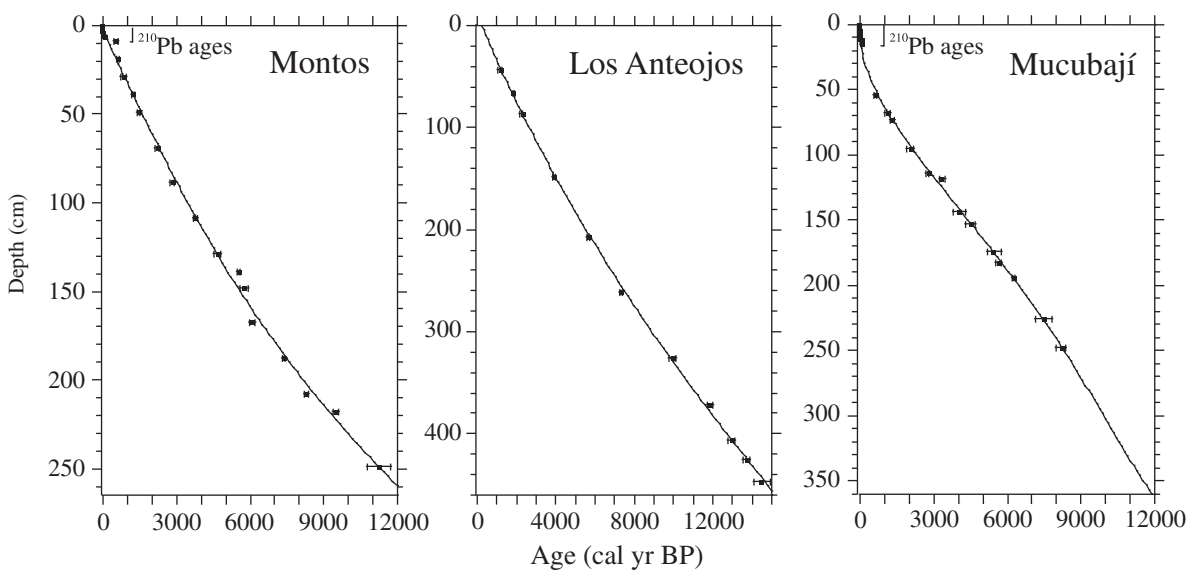

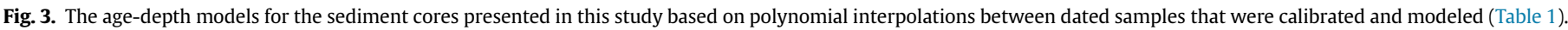
The age models for the upper $\sim 20 \mathrm{~cm}$ of the Mucubaji and Montos records were dated using ${ }^{210} \mathrm{~Pb}$ methods.

measurable calcium carbonate in the sediments. Magnetic susceptibility was measured at $0.2 \mathrm{~cm}$ intervals (excluding the flocculent surface sediment) using a Tamiscan high-resolution surface scanning sensor connected to a Bartington susceptibility meter at the University of Pittsburgh. The top $29 \mathrm{~cm}$ of the Los Anteojos surface core were measured for magnetic susceptibility using $8 \mathrm{~cm}^{3}$ plastic cubes filled with sediment and analyzed using a Bartington MS2B dual frequency sensor connected to a Bartington susceptibility meter.

Bulk sediment geochemistry was measured by a combination of methods. First, sediment cores were measured at $0.1 \mathrm{~cm}$ spacing using an ITRAX scanning X-ray fluorescence (XRF) instrument (Croudace et al., 2006) at the University of Minnesota-Duluth Large Lakes Observatory. The XRF results for the Montos and Mucubají records are presented in counts per second (CPS). For the extruded section of the Los Anteojos surface core (top $29 \mathrm{~cm}$ ), samples were taken every $0.5-1.0 \mathrm{~cm}$, freeze-dried and measured using an Innov-X Professional ${ }^{\circledR}$ handheld XRF instrument at Northern Illinois University. Five $1 \mathrm{~cm}$-thick samples were also collected at $30-50 \mathrm{~cm}$ intervals from the lower $1.5 \mathrm{~m}$ of the Los Anteojos core (Supplemental Table 1 in Stansell et al., 2010), and measured by ICP-AES and ICP-MS at the ALS Chemex facility in Reno Nevada. This enabled us to convert scanning XRF values to units of concentration using linear regression techniques (Stansell et al., 2013a), and to merge the geochemical data from the long cores with the extruded samples for Los Anteojos.

\subsection{Biogenic silica and clastic sediment concentrations}

Weight percentage biogenic silica $\left(\mathrm{bSiO}_{2}\right)$ for the Los Anteojos and Montos cores were measured on freeze-dried samples at the University of Alberta Department of Earth and Atmospheric Sciences, and the LacCore facility at the University of Minnesota, respectively. The samples were measured following established protocols (DeMaster, 1979, 1981; Conley, 1998). Biogenic silica concentrations for Laguna de Mucubají were measured at the Quaternary Laboratory at the University of Massachusetts (Polissar, 2005; Stansell et al., 2005; Polissar et al., 2006b) using similar methods. Biogenic silica content is also represented by $\mathrm{Si} / \mathrm{Ti}$ values measured using scanning XRF (Brown et al., 2007; Stansell et al., 2010). The $\mathrm{Si} / \mathrm{Ti}$ values were converted to percent $\mathrm{bSiO}_{2}$ for all three records using linear regression methods (Stansell, 2009; Stansell et al., 2010). The $\mathrm{bSiO}_{2}$ fraction for the field extruded top $29 \mathrm{~cm}$ of the Los Anteojos record was calculated by multiplying the organic matter concentration values by 0.74 , following similar methods in Stansell et al. (2005). The clastic sediment content for all lake sediment records was calculated as the residual after summing the percentages of organic matter and biogenic silica, and subtracting this value from $100 \%$, since there is no carbonate present. Clastic sediment concentrations for all records were converted to flux values $\left(\mathrm{g} / \mathrm{cm}^{2} / \mathrm{yr}\right)$ by multiplying the clastic component of dry bulk density $\left(\mathrm{g} / \mathrm{cm}^{3}\right)$ by sedimentation rate $(\mathrm{cm} / \mathrm{yr})$.

\section{Results}

\subsection{Sedimentology and geochemistry}

There are two clear end-member sediment facies in the Venezuelan proglacial sediment records. There are sections dominated by fine-grained clastic (minerogenic) sediment characterized by high values of titanium (Ti), iron (Fe), magnetic susceptibility and dry bulk density. These clastic-rich sediment sections are low in organic-matter content and biogenic silica, and are light gray in color (GLEY $18 / 1$ ). In contrast, there are sections with low clastic sediment content that have correspondingly low values of $\mathrm{Ti}, \mathrm{Fe}$, magnetic susceptibility and dry bulk density. These sections with low clastic sediment content have relatively high concentrations of organic-matter and biogenic silica, and are dark brown in color (7.5YR 2.5/1). The geology and main geochemical proxies for clastic sediment are consistent across multiple valleys, and bedrock near all glacier headwalls is comprised mostly of metasedimentary rocks with high concentrations of $\mathrm{Ti}$ and Fe. Clastic sediment flux generally tracks other proxies for clastic sediments, with notable exceptions described below.

\subsubsection{Laguna Montos}

The Laguna Montos sediment record spans the Holocene and records changes in sediment composition in the valley below Pico El Toro and Pico El Leon (Fig. 4). Multiple proxies for clastic sediment values were high from $\sim 12$ to $11 \mathrm{ka}$, followed by an overall decreasing trend through the early Holocene that is punctuated by decadal to multi-centennial scale shifts to higher values. The early Holocene section also contains relatively low amounts of biogenic silica and organic matter. Proxies for clastic sediments then have low values during the middle Holocene from $\sim 8.0$ to $7.8 \mathrm{ka}$, followed by intermediate values until $\sim 6.5 \mathrm{ka}$. Overall, the remaining upper section of the middle Holocene is characterized by relatively low amounts of clastic sediments. Biogenic silica and organic matter concentrations are generally higher in the middle Holocene section than the early Holocene. The late Holocene is characterized 


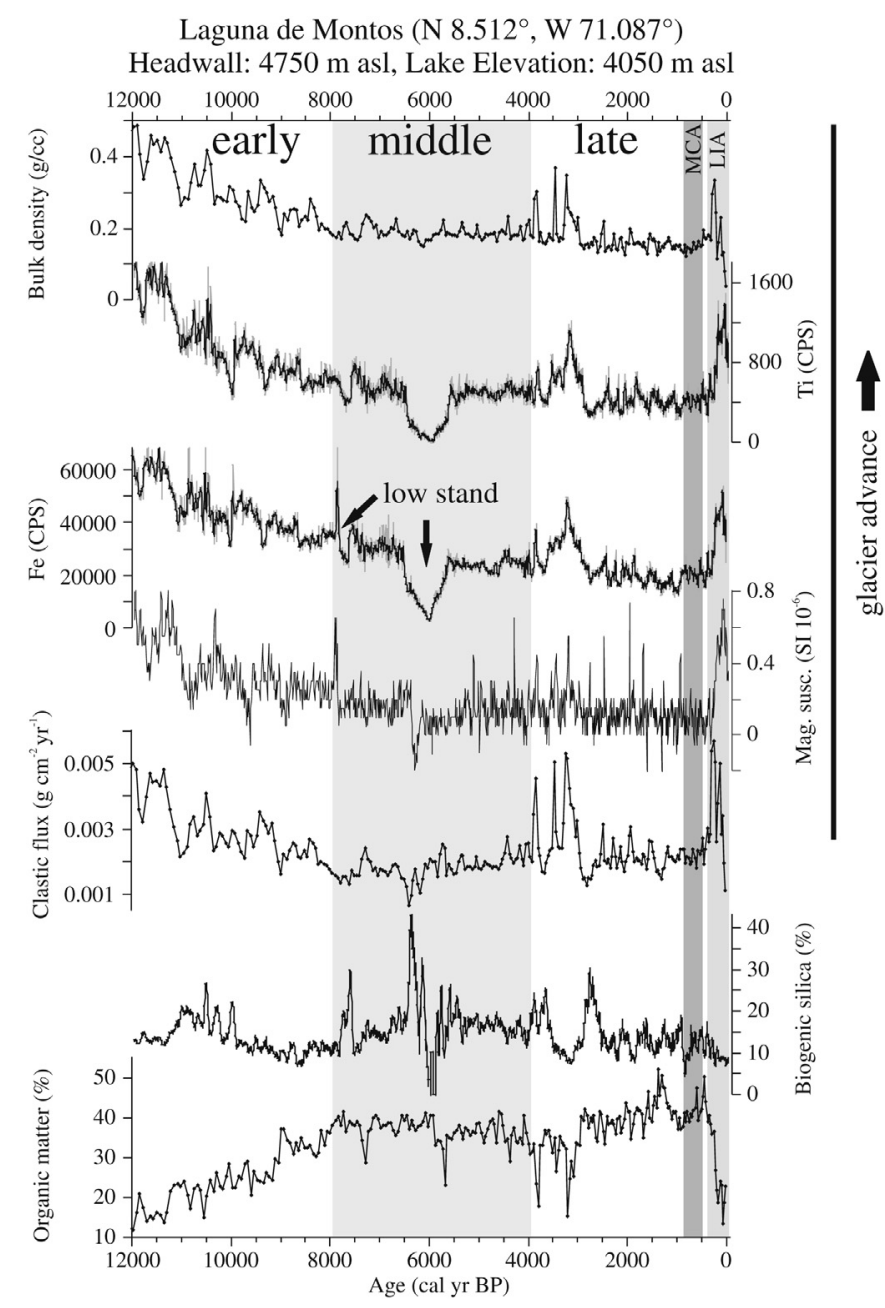

Fig. 4. Sediment core data for Laguna Montos including dry bulk density $\left(\mathrm{g} \mathrm{cm}^{-3}\right)$, titanium (Ti) and iron (Fe) in counts per second (CPS), magnetic susceptibility (SI units), clastic sediment flux $\left(\mathrm{g} \mathrm{cm}^{-2} \mathrm{yr}^{-1}\right.$ ), biogenic silica (10 pt moving average, wt \%), and organic matter (wt \%). The shading in gray denotes the middle Holocene, MCA and LIA. The background shading for the Ti and Fe plots illustrates the raw data and the black represents the 10 -point moving averages.

by overall high values for multiple clastic sediment proxies from $\sim 4.0$ to $3.0 \mathrm{ka}$, followed by generally lower values through much of the remaining interval. The upper $\sim 400$ years of the Montos record contains a pronounced increase in proxies for clastic sediment values.

\subsubsection{Laguna de Los Anteojos}

The Los Anteojos sediment record spans the Holocene and records changes in sediment composition in the valley adjacent to Pico Espejo (Fig. 5). There is an overall decreasing trend for multiple proxies of clastic sediments during much of the Holocene in the Los Anteojos record, upon which centennial to millennial-scale variability is superimposed. For example, values for bulk density, Ti, Fe, magnetic susceptibility and clastic sediment flux decreased from $\sim 12.0$ to $11.0 \mathrm{ka}$, followed by a shift to higher values until $\sim 10.0 \mathrm{ka}$. Biogenic silica and organic matter concentrations are relatively low in the $\sim 12.0-11.5$ ka section, followed by a shift to higher values until $\sim 10.0 \mathrm{ka}$. After $\sim 10.0 \mathrm{ka}$, there are relatively stable, intermediate clastic sediment and organic matter values as biogenic silica concentrations decrease until $\sim 8.0 \mathrm{ka}$. After $8.0 \mathrm{ka}$, multiple proxies indicate that a major shift in sediment composition

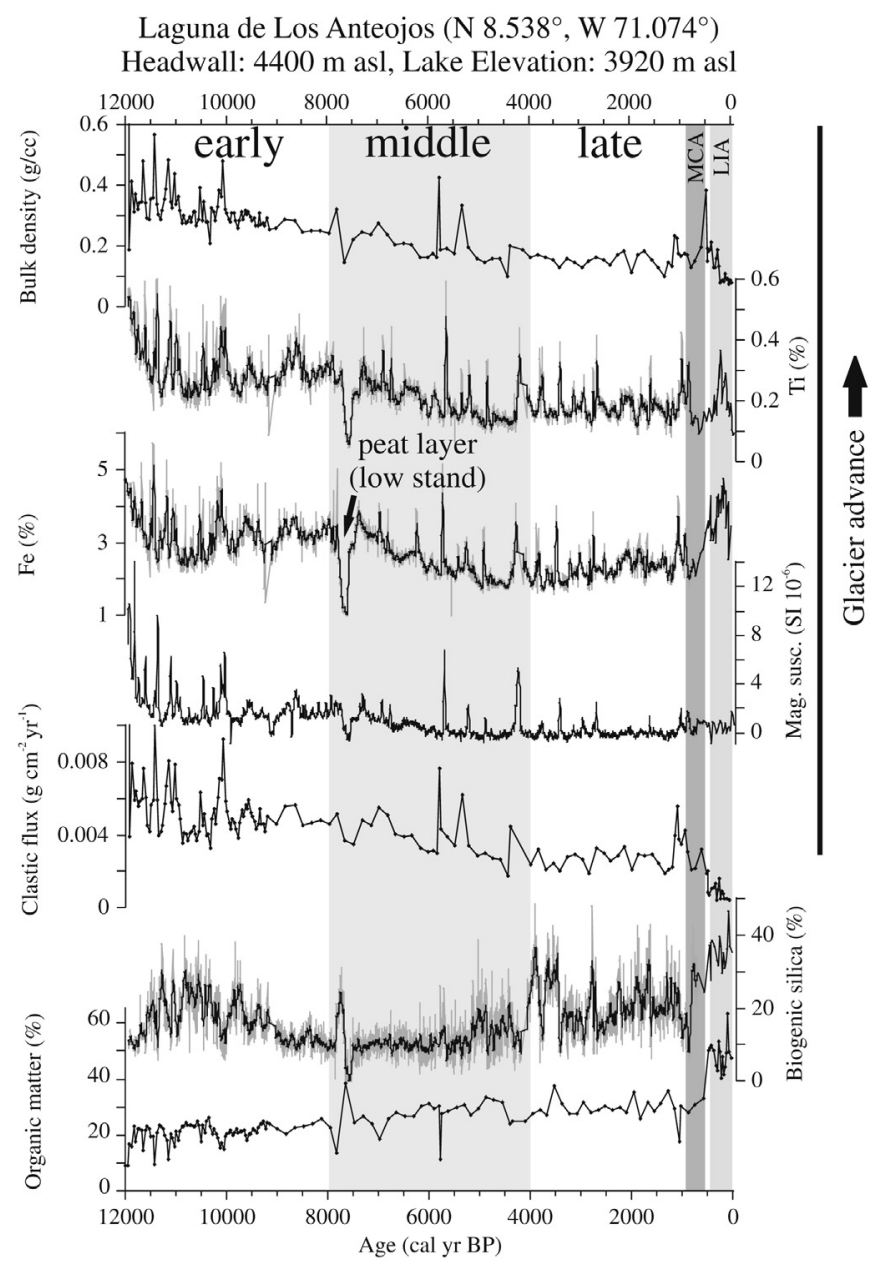

Fig. 5. Sediment core data for Laguna de Los Anteojos including dry bulk density, titanium (Ti) and iron (Fe) as percentages (\%), magnetic susceptibility (SI units), clastic sediment flux ( $\mathrm{g} \mathrm{cm}^{-2} \mathrm{yr}^{-1}$ ), biogenic silica (wt \%), and organic matter (wt \%). The shading in gray denotes the middle Holocene, MCA and LIA. The background shading for $\mathrm{Ti}$ and $\mathrm{Fe}$ plots illustrates the raw data and the black represents the 10-point moving averages. The background shading for the biogenic silica plot illustrates the raw data and the black shows the 10-point moving averages for the section between $12 \mathrm{ka}$ and $0.6 \mathrm{ka}$. The upper $\sim 600$ years of Ti, Fe and biogenic silica data are based on measurements from the extruded samples, and values were not smoothed.

occurred, with higher organic matter and biogenic silica concentrations that lasted until $\sim 7.5 \mathrm{ka}$. This section of the core is also dominated by macrofossils resembling fossilized peat remains. Proxies for clastic sediments follow a decreasing trend from $\sim 7.5$ to $4.5 \mathrm{ka}$ and remain at intermediate values in the remaining middle Holocene section. Biogenic silica and organic matter concentrations overall increase during the middle Holocene from $\sim 7.5$ to $4.0 \mathrm{ka}$. The upper section of the core $(\sim 4.0-0.6 \mathrm{ka})$ contains mostly low to intermediate values for clastic sediment proxies with brief periods of higher values. The Ti, Fe, organic matter and biogenic silica values are high in the top $\sim 600$ years of the record, and the bulk density, magnetic susceptibility and clastic sediment flux values are low in this section of the core.

\subsubsection{Laguna de Mucubají}

The Laguna de Mucubají record spans the Holocene and records changes in sediment composition in the valley below Pico Mucuñuque (Fig. 6). There is an overall decreasing trend in proxies for clastic sediments through the Holocene that is interrupted by multiple centennial to millennial-scale periods of higher values. 


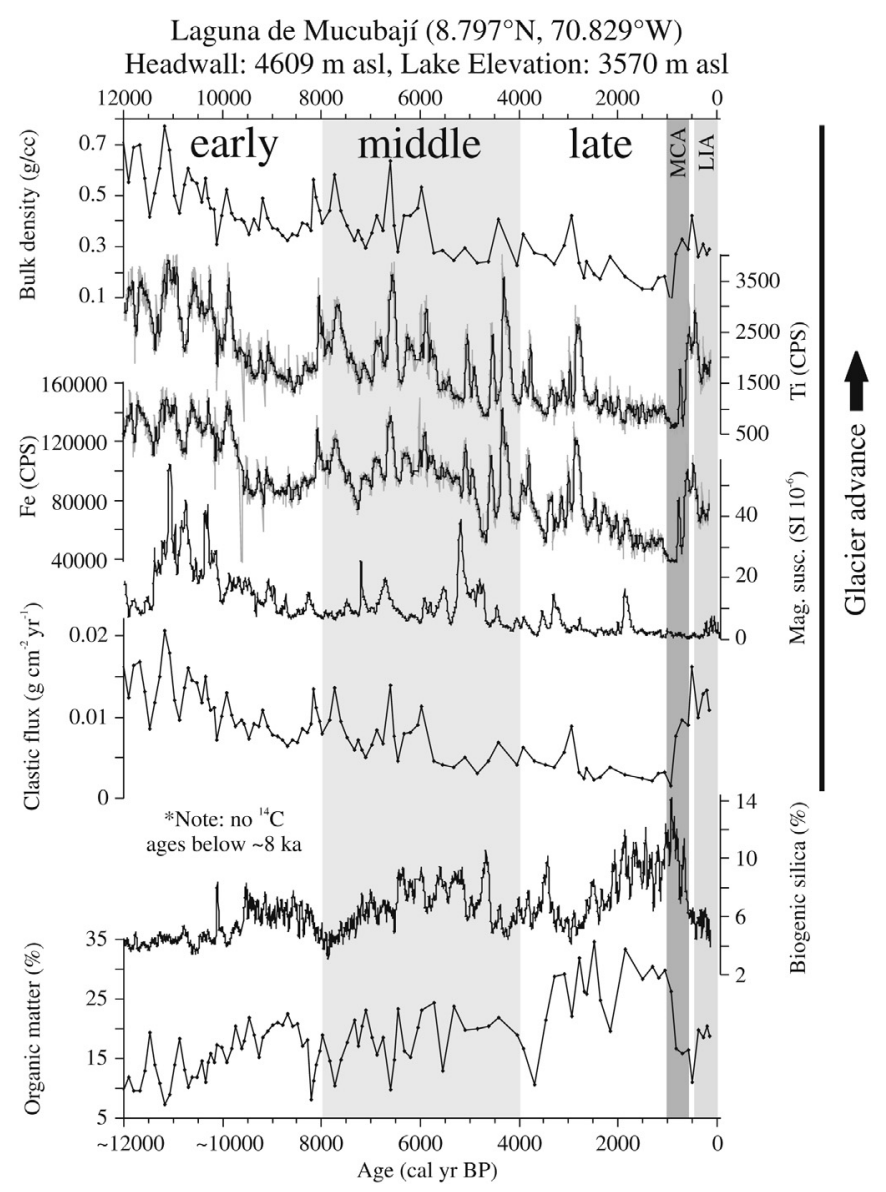

Fig. 6. Sediment core data for Laguna de Mucubají including dry bulk density $\left(\mathrm{g} \mathrm{cm}^{-3}\right)$, titanium (Ti) and iron (Fe) in counts per second (CPS), magnetic susceptibility (SI units), clastic sediment flux ( $\mathrm{g} \mathrm{cm}^{-2} \mathrm{yr}^{-1}$ ), biogenic silica (wt \%), and organic matter (wt \%). The shading in gray denotes the middle Holocene, MCA and LIA. The background shading for the Ti and Fe plots illustrates the raw data and the black represents the 10-point moving averages. The ages older than $\sim 8$ ka should be considered minimum ages, because they are extrapolated based on average sedimentation rates of sections higher in the core.

The record contains variable, but high amounts, of clastic sediments with low values of biogenic silica and organic matter from $\sim 12.0$ to $10.0 \mathrm{ka}$. An abrupt decrease in clastic sediment proxy values occurs at $\sim 10.0 \mathrm{ka}$, followed by a continuing trend toward lower values until $\sim 8.5 \mathrm{ka}$. Likewise, a bog sediment core collected in 2007 from the uppermost terrace in the watershed (3990 $\mathrm{m}$ asl) contains an abrupt transition from almost entirely clastic sediment $(>80 \%)$ to highly organic-rich (>60\%) material at a depth of $130 \mathrm{~cm}$ (Table 1). A radiocarbon age from a macro-fossil sample taken immediately above this transition yielded a median value of $9.1 \mathrm{ka}$, and another macro-fossil sample from $2 \mathrm{~cm}$ above the transition dated to $9.0 \mathrm{ka}$. Biogenic silica and organic matter values in the lake sediment record are overall intermediate from $\sim 10.0$ to $4.5 \mathrm{ka}$, with brief periods of lower values during the early to middle Holocene transition. There are distinct increases in geochemical proxies for clastic sediments in the Mucubaji lake sediment core centered on $\sim 8.1$ and $7.7 \mathrm{ka}$, followed by decreasing values until $\sim 7.0 \mathrm{ka}$. Another increase in clastic sediment proxy values occurred from $\sim 7.0$ to $6.6 \mathrm{ka}$ followed by overall decreasing values until $\sim 5.2 \mathrm{ka}$. There were then intermittently high, but overall decreasing clastic sediment proxy values from $\sim 5.0$ to $4.0 \mathrm{ka}$. Another phase of lower clastic sediment proxy values occurred at the start of the late Holocene from $\sim 4.0$ to $3.5 \mathrm{ka}$, followed by a shift to higher values around $3.0 \mathrm{ka}$. The section from $\sim 2.5$ to $0.7 \mathrm{ka}$ contains the lowest average values for clastic sediment proxies for the entire Holocene section of the Mucubaji record along with high values of organic matter and biogenic silica. The upper $\sim 700$ years of the record are characterized by overall higher values for clastic sediment proxies, along with lower biogenic silica and organic matter values.

\section{Discussion}

A host of previous studies demonstrate that lake sediment records from the tropical Andes can be used to identify changes in the extent of climate-mediated up-valley ice cover (Abbott et al., 2003; Stansell et al., 2005; Polissar et al., 2006b; Rodbell et al., 2008; Stansell et al., 2010, 2013a). Clastic sediments in each of the records presented here are fine-grained, and when interpreted within the context of a multiproxy study, down-core variations in fine-grained clastic sediment proxies (including physical properties, geochemistry and magnetic susceptibility) reveal temporal patterns of glacial advance and retreat. In Andean watersheds, increases in clastic sediment proxies generally reflect active erosion by a growing glacier; whereas a decrease in clastic sediment proxies can reflect ice marginal retreat (e.g. Harbor and Warburton, 1992). Glacier retreat can also generate high rates of periglacial sediment yield when erosion of glacially derived sediment occurs on steep, unvegetated landscapes (Smith and Ashley, 1985; Nussbaumer et al., 2011), but this is probably a secondary influence in this relatively wet region because small, warm-based glaciers in steep terrain constantly drain large amounts of water, leaving a limited sediment supply on the landscape when the glacier retreats. These watersheds are also vegetated, and have been since the Lateglacial stage (Rull et al., 2005, 2010), further reducing the likelihood that periglacial processes were a major influence on clastic sediment delivery at these locations.

In addition to glacial processes and the factors mentioned above, clastic sediment delivery to Andean lakes is influenced by basinspecific processes that operate in the absence of glacigenic sediment. We emphasize, however, that sediment records from most previously published lake basins in the Venezuelan Andes show little or no pronounced change in clastic sediment input over the last $\sim 10 \mathrm{ka}$ (Stansell et al., 2005), because they were outside the glacial limit. If precipitation, not glaciation, was the primary control during the Holocene on clastic sedimentation in these systems, then records from both glaciated and non-glaciated valleys should have similar patterns (Rodbell et al., 2008), which is not the case for the Mérida Andes. The lack of clastic sediment accumulation in lower elevation sites is likely because most of the lake basins in the Venezuelan Andes have relatively small catchments and silicaterich metamorphic bedrock that are resistant to erosion by fluvial and surface runoff processes (e.g. Sklar and Dietrich, 2001). This implies that glacial erosion is needed to produce the substantial amounts of clastic sediments that we observe in the sediment records presented here. Given the proximity of the Boconó fault system to the Mucubají watershed (Fig. 2), another important factor that must be considered is that past seismic activity can influence the amount and source of sediment (Audemard, 1997; Carrillo et al., 2008); however this does not explain why all three records presented here show similar patterns during the Holocene when the mapped faults that affect the Mucubaji valley do not cut through either the Montos or Los Anteojos catchments (Hackley et al., 2005). Therefore glacial processes, and not seismic events or erosion by precipitation, are the primary control on clastic sediment input at these study sites (Stansell et al., 2007a).

Further validation of our clastic sediment interpretation is provided by the confirmation of our previous lake-sediment based chronologies for late Pleistocene and early Holocene deglaciation 
(e.g. Stansell et al., 2005; Stansell et al., 2010) based on independent surface exposure ages. For example, newly published ${ }^{10} \mathrm{Be}$ exposure ages on Lateglacial stage moraines in the Mucubají watershed and surrounding region are available (Wesnousky et al., 2012; Carcaillet et al., 2013). Even though these ages should be recalculated using the new calibrated tropical production rates (Kelly et al., in press), the available ages for the timing of deglaciation in the upper region of the Mucubají valley, based on ${ }^{10} \mathrm{Be}$ methods (Carcaillet et al., 2013), generally correspond to the timing of shifts in clastic sediment values in the lake and bog cores discussed here and in past studies. These records are discussed in greater detail below.

With the above considerations in mind, we interpret the clastic sediment records as largely reflecting the presence and level of activity of advancing glaciers within a watershed. Multiple geochemical and sedimentological proxies for catchment erosion document the production of clastic sediments within the lake catchments, including congruent changes in sediment density, magnetic susceptibility and geochemical tracers of input from the metasedimentary rocks (principally $\mathrm{Ti}$ and Fe). Furthermore, periods of high clastic sediment influx dilute the organic matter and biogenic silica, leaving a distinct signature in the sediments. While future work aimed at directly dating glacial landforms will improve our understanding of glacial history, our prior work in the tropical Andes suggests that well-dated clastic lake sediment records provide a robust method for reconstructing glacier activity (Stansell et al., 2010, 2013a).

\subsection{Glacial variability during the early Holocene ( 12.0-8.0 ka)}

The sedimentological and geochemical data from Lagunas Montos, Los Anteojos and Mucubají, show an overall decreasing trend in multiple proxies for clastic sediments during the transition from the Lateglacial stage into the Holocene, but there are several periods of ice advance that interrupt the overall deglacial trend in the northern Andes. For example, ice margins advanced under colder conditions at the start of the Younger Dryas at $\sim 12.9 \mathrm{ka}$, and stayed advanced for several centuries until warming initiated (Rull et al., 2010; Stansell et al., 2010). After $\sim 11.8 \mathrm{ka}$, there were a series of brief ( $\sim 200-300$ years) readvances that occurred until $\sim 10 \mathrm{ka}$. A major phase of deglaciation then occurred at $\sim 10 \mathrm{ka}$ as numerous catchments with headwalls $<4000 \mathrm{~m}$ became ice free for most of the remaining Holocene (Stansell et al., 2005). The timing of this transition also corresponds to a previously published basal age from a peat core on a lateral moraine in the valley that dates to $\sim 10.0 \mathrm{ka}$ (Stansell et al., 2005). The sediment record presented here, from the upper terrace bog in the Mucubají valley (3990 $\mathrm{m}$ asl), shows clastic-rich sediment capped by peat at $\sim 9.0 \mathrm{ka}$, providing further evidence that the local glacier retreated in the early Holocene (Table 1 ). Polished bedrock collected nearby the upper terrace bog core site has a cosmogenic radionuclide exposure age of $\sim 9.7 \mathrm{ka}$ (Carcaillet et al., 2013), providing further support for a phase of deglaciation in the watershed at that time. This widespread deglaciation was followed by either low, or a continuing trend toward decreasing clastic sediment values from $\sim 10$ to $8.0 \mathrm{ka}$.

The period of overall glacial retreat in the Venezuelan Andes during the early Holocene took place when other proxy records from the region suggest conditions were wetter and temperatures were increasing in the northern tropics. For example, a lake level record from Laguna Blanca suggests a relatively higher precipitation/evaporation ratio and higher water levels (Fig. 7). Stable isotope measurements from nearby Lagunas Baja and Alta also indicate wetter conditions (Polissar et al., 2006a, 2013). Likewise, land-based records from the Caribbean are similar to the patterns recorded in the Cariaco Basin sediments and indicate that

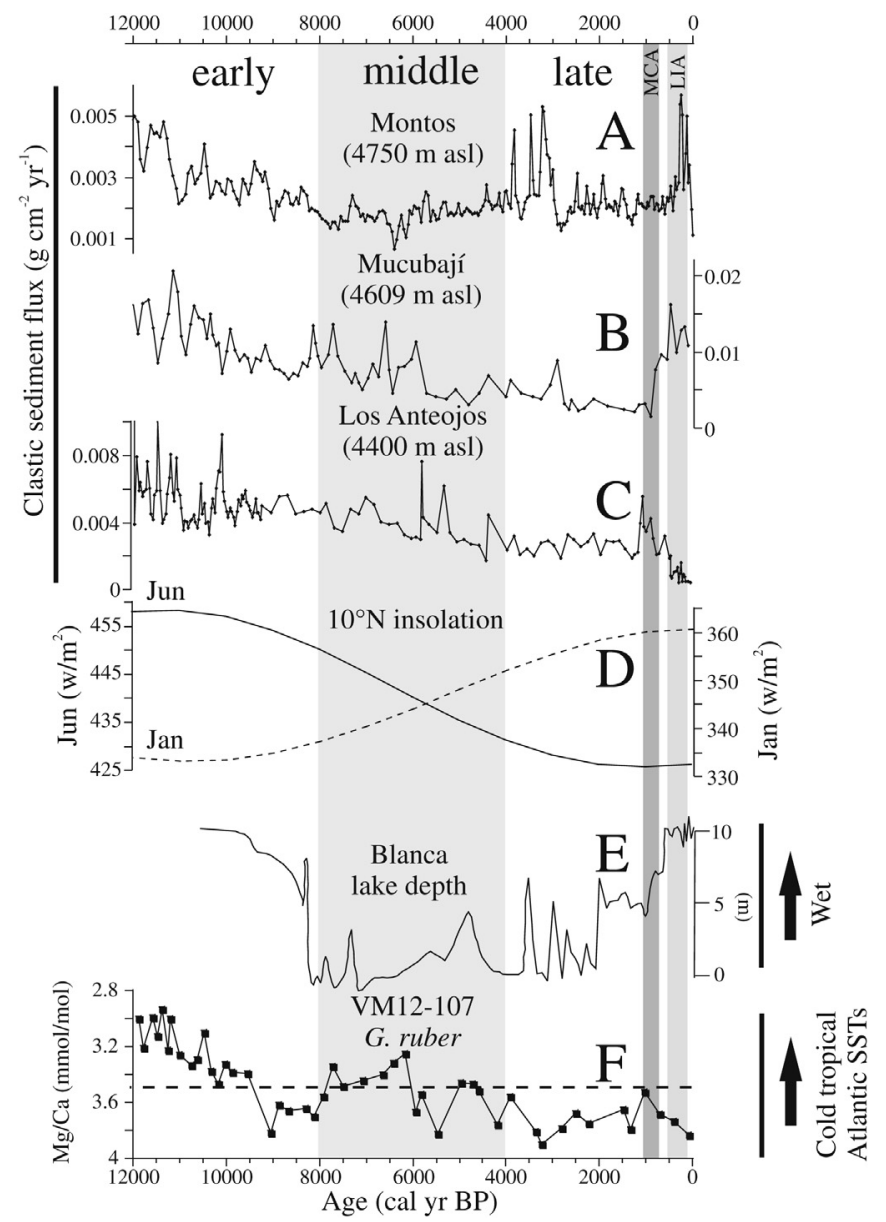

Fig. 7. Clastic sediment flux values for Montos, Mucubají and Los Anteojos (A-C) plotted versus summer and winter insolation values (D) for the northern tropical Andes. Shading denotes the middle Holocene, MCA and LIA. Summer insolation decreased and winter insolation increased in the northern tropics during the Holocene (Berger and Loutre, 1991). The record of water depth changes from Laguna Blanca (E) indicates that it was wet in the early and late Holocene, and dry during the middle Holocene (Polissar, 2005). Although there is pronounced centennial and millennialscale variability in the record, there is an overall pattern of retreating glaciers during the Holocene through the MCA, followed by a pronounced advance during the LIA. Glacial variability in Venezuela generally tracks colder conditions recorded in the northern tropical Atlantic (F) (Schmidt et al., 2012).

conditions there become wetter in the early Holocene (Hodell et al., 1991; Curtis and Hodell, 1993; Haug et al., 2001). Given that conditions appear to have been wetter throughout much of the region during the early Holocene, warming temperatures appear to have been the primary driver of early Holocene glacial retreat. Indeed, proxy records from the tropical Atlantic off the coast of Venezuela suggest conditions were cold at the beginning of the Holocene when glaciers in the Mérida Andes appear to have been advanced, followed by a warming trend concurrent with decreased or stabilized clastic sediment flux in the records presented here (Fig. 7).

\subsection{The middle-Holocene ( $8.0-4.0 \mathrm{ka})$}

The middle Holocene in the Venezuelan Andes was a period with a complicated pattern of ice margin fluctuations and/or precipitation changes. For instance, there was an abrupt transition to lower $\mathrm{Ti}$ and $\mathrm{Fe}$ values in the Montos and Los Anteojos basins at $\sim 8.0$ ka that lasted $\sim 300$ years. At the same time in the Los Anteojos record (Fig. 5), a $\sim 10 \mathrm{~cm}$-thick peat horizon indicates that precipitation-fed runoff to the lake was greatly reduced. There is 
also evidence suggesting that ice margins advanced in the Mucubají catchment during the first half of the middle Holocene, followed by retreat in the second half (Fig. 6). If a middle Holocene advance took place above Mucubají, it was limited to the highest elevations of the catchment, because the $9.0 \mathrm{ka}$ basal age on the upper terrace bog record precludes any ice advances below $3990 \mathrm{~m}$ asl after that time. Nevertheless, the abrupt transition at $\sim 6.3$ ka from mostly coarsegrained clastic sediments to peat, recorded in the Mucubají recessional moraine bog (3700 m asl; Fig. 2), provides further evidence that a middle Holocene advance occurred somewhere upvalley, followed by a deglacial trend during the late stages of middle Holocene (Stansell et al., 2005). The Montos sediment record also has very low clastic sediment values (Fig. 4), providing corroborating evidence of mostly ice free conditions $\sim 6.0 \mathrm{ka}$, and further suggesting that the pattern of ice retreat in the Mucubaji valley during the latter stages of the middle Holocene occurred within multiple watersheds in the region.

Our suggestion in Stansell et al. (2005) that ice advanced, or was present, during the middle Holocene in the Mucubaji catchment has been challenged because there are multiple controls on clastic sediment delivery that must be considered besides glaciation (Mahaney et al., 2007). Indeed, the other records presented here (Montos and Los Anteojos) do not show evidence of middle Holocene ice advances that is as strong as that inferred for Mucubají. We interpret the decreasing trend in clastic sediment during the middle Holocene in the Montos and Los Antejos records as an indication that the slopes of the watersheds stabilized following the early Holocene phase of ice retreat in those respective valleys rather than evidence of advancing ice. We assert, however, that it is difficult to explain the middle Holocene increase in clastic sediment accumulation in the Mucubají valley as anything other than evidence of an ice advance (Stansell et al., 2007a). Moreover, proxy records from the tropical Atlantic off the coast of Venezuela suggest that there was a shift to colder conditions during the first half of the middle Holocene when sedimentological evidence from the Andes suggests a glacial readvance occurred, followed by higher temperatures during the latter stages of the interval when ice apparently retreated (Fig. 7; Schmidt et al., 2012). Nevertheless, further independent ages on glacial landforms in the Mucubají valley and improved documentation of past seismic activity should be explored in future studies to provide either supporting or refuting evidence of middle Holocene glacier advances.

The pattern of middle Holocene climate variability in the northern tropics is also preserved in other proxy records from the region. Notably, the Cariaco Basin Ti record suggests conditions were wetter in the region during the early and middle Holocene (Haug et al., 2001), which is not entirely consistent with records from the Venezuelan Andes. First, a reconstruction of lake-level changes in Laguna Blanca in the northern Andes indicates that conditions were relatively dry during the middle Holocene (Fig. 7; Polissar et al., 2013). Palynological evidence from the Venezuelan Andes corroborates the geochemical data, suggesting that the middle Holocene was drier than the early Holocene (SalgadoLabouriau, 1986; Rull et al., 2005). Likewise, the timing of major low lake stands during the middle Holocene corresponds to a similar abrupt shift to low water levels from $\sim 8.2$ to 7.3 ka at Lago de Valencia (located in the lowlands of northern Venezuela) (Bradbury et al., 1981; Curtis et al., 1999). Los Anteojos is $\sim 8 \mathrm{~m}$ deep and overflowing today, indicating that conditions must have been much drier for peat to form in this basin at the start of the middle Holocene. Moreover, the clastic sediment proxies in the Los Anteojos and Montos basins approached their lowest values of the entire Holocene at $\sim 6 \mathrm{ka}$, suggesting that runoff and/or glacial melt in these watersheds was reduced at that time. Thus, the lacustrine records from the Venezuela Andes indicate that conditions were drier during the middle Holocene at the same time the Cariaco Basin records suggest precipitation was higher in northern South America.

\subsection{Late Holocene (4.0 ka to present)}

The late Holocene sections of the sediment records presented here have overall low clastic sediment content and high values of organic matter, but there are some noteworthy changes that punctuate this interval. For example, the Mucubají record shows a pronounced increase in several proxies for clastic sediments centered on $\sim 3 \mathrm{ka}$ (Fig. 6), and the Montos profile shows similar increases around that time (Fig. 4). The start of the Medieval Climate Anomaly (MCA) of the Northern Hemisphere at $\sim 1.0 \mathrm{ka}$ is expressed in the Montos and Mucubají records as a period of generally lower clastic sediment influx. Likewise, most proxies for terrigenous sediments in the Los Anteojos record have lower values during the MCA even though there are intermediate values for bulk density and clastic sediment flux. In the Mucubají record ( $\sim 4609 \mathrm{~m}$ asl), an increase in multiple proxies for clastic sediments occurs at $\sim 0.7 \mathrm{ka}$, marking the onset of colder conditions in the northern tropical Andes during the Little Ice Age (LIA) (Polissar et al., 2006b). A LIA advance is likewise apparent in the upper $\sim 400$ years of the Montos record ( $\sim 4750 \mathrm{~m}$ asl), with pronounced increases in multiple proxies for clastic sediments. Overall, the Los Anteojos record suggests that there was not a LIA advance in that catchment, providing evidence that the glaciation limit did not extend to elevations as low as $\sim 4400 \mathrm{~m}$ asl. It is also possible that some of the variability in the clastic sediment records from the different watersheds reflects basin specific processes (Mahaney et al., 2007); however the shift to higher values is apparent in both the Montos and Mucubaji records, providing evidence from multiple sites that the region was colder during the LIA and consistent with historical records of ice being present (Jahn, 1925; Schubert, 1992; Braun and Bezada, 2013). Collectively these data indicate that the freezing height during the LIA in Venezuela was at least as low as $\sim 4600 \mathrm{~m}$ asl. Today's freezing height in Venezuela is $\sim 4860 \mathrm{~m}$ asl (Stansell et al., 2007b), and the lack of a LIA glacier near Los Anteojos is consistent with a possible $300-500 \mathrm{~m}$ lowering of equilibrium line altitudes during the LIA (Polissar et al., 2006b), because the headwall in that valley is likely too low to have been glaciated.

\subsection{Causes of Holocene glacier variability in the Venezuelan Andes}

It is apparent that ocean and atmospheric processes from both the Atlantic and Pacific contributed to climate variability in the tropical Andes during the Holocene, even though the influence of dynamics and teleconnections across these basins on high altitude conditions is not currently well understood. Glaciers in Venezuela are mostly temperature sensitive (e.g. Stansell et al., 2007b), and atmospheric conditions in the tropical Andes are largely affected by shifting equatorial SSTs (Vuille et al., 2008; Bradley et al., 2009). Decreased clastic sediment flux in multiple watersheds appears to be associated at times with warmer temperatures in the tropical Atlantic (Fig. 7). Likewise, shifting mean-state conditions in the tropical Pacific during the Holocene (e.g. Clement et al., 2000; Cobb et al., 2013) could have affected atmospheric conditions in the Venezuelan Andes. Today, colder northern tropical Andean temperatures are associated with colder tropical ocean surface conditions in both the Pacific and Atlantic (Vuille et al., 2000), but this relationship on longer time-scales over the Holocene has not been well established. Moreover, the teleconnections between the Pacific 
Ocean and Atlantic Ocean and atmospheric processes need to be further evaluated in order to better understand the causes of atmospheric variability in the tropical Andes during the Holocene (Stansell et al., 2013a). Nevertheless, Holocene glaciers in Venezuela generally retreated during times of warmer tropical SSTs and advanced during colder periods.

The observed early Holocene sedimentological changes underscore the importance of ocean and atmospheric processes in driving Andean climate changes. This pattern of decreased erosion and/or increased watershed stability is apparent in multiple sediment records from the region which all show decreasing clastic sediment values. It is noteworthy that clastic sediment values were initially high during the early Holocene while Northern Hemisphere summer insolation values were elevated, but on a decreasing trend (Fig. 7). High tropical precipitation amounts tied to orbital processes (e.g. Baker et al., 2001; Haug et al., 2001) could explain the elevated clastic sediment flux values during the early Holocene, but for reasons discussed here, it is more likely that these changes in sediment content were driven by glacial processes. Moreover, the rapid sedimentological changes that are observed in multiple records during the early Holocene, and later, cannot be explained by gradually decreasing summer insolation values (Hodell et al., 1991); hence there must be additional forcing mechanisms at play on shorter time-scales, like shifting ENSO mean-state conditions (e.g. Polissar et al., 2013) and tropical Atlantic temperature and circulation changes (e.g. Schmidt et al., 2012).

The broad Holocene pattern of lake level changes presented here can also be compared to infer past climate linkages to the tropical Pacific and Atlantic oceans. The South American Summer Monsoon on centennial and longer time-scales is sensitive to Atlantic Ocean conditions, and the monsoon generally became stronger during the Holocene (Bird et al., 2011a). A stronger monsoon system alone does not explain the full pattern of climatic variability that took place in the tropical Andes, especially in the Northern Hemisphere (Polissar et al., 2013; Stansell et al., 2013a). Today, higher precipitation amounts in the Venezuelan highlands are most strongly correlated to cold SSTs in the Niño 3.4 region (Pulwarty et al., 1992; Polissar et al., 2013), and paleorecords of equatorial Pacific SSTs (Tudhope et al., 2001; Koutavas et al., 2006) suggest that ENSO variability was reduced during the middle Holocene and similar to present in the early and late Holocene (Polissar et al., 2013). Thus, even though the Atlantic Ocean no doubt played a role in tropical Andean climate change during the Holocene, the pattern of observed precipitation changes in Venezuela is possibly better explained by variability in the equatorial Pacific Ocean.

The middle Holocene pattern of lake level fluctuations and changes in glacial activity provides further evidence that tropical Andean climate changes cannot be explained by insolation forcing alone. Ice margins in Venezuela retreated during the middle Holocene as summer insolation values decreased in the northern tropics (Fig. 7). In the southern tropics, glaciers advanced during the middle Holocene when summer insolation values were increasing (Stansell et al., 2013a). Higher summer (wet season) insolation typically leads to wetter conditions in the tropical Andes (Seltzer et al., 2000), but the submillennial-scale formation of peat in the Los Anteojos sediment record, and the lower lake levels of Laguna Blanca took place at a time when summer insolation values in the northern tropics were relatively high (Fig. 7). Stable isotope records from Lagunas Verde Baja and Alta in Venezuela likewise indicate that conditions were drier at that time (Polissar et al. 2006a). Winter insolation values were increasing during the middle Holocene, and perhaps a seasonal threshold in solar radiation energy was crossed that led to more arid conditions. Regardless, this pattern of drying is consistent with other records from both the northern and southern tropics, and is likely better explained by oceanic and atmospheric, rather than orbital, processes. As discussed above, the tropical Pacific Ocean and the dynamics of ENSO, are examples of systems capable of producing the observed pattern of Holocene lake level and glacial changes in both the northern and southern hemispheres of South America (e.g. Polissar et al., 2013).

Discerning the pattern of late Holocene climatic changes in the northern and southern tropical Americas requires careful consideration of both terrestrial and ocean-based paleoproxy data. For example, changes in the concentration of titanium in Cariaco Basin sediments, and stable isotope records from Central America suggest that the MCA was relatively wet, and the LIA was drier in the northern tropics (Haug et al., 2001; Hodell et al., 2005; Stansell et al., 2013b). In contrast, records from the Venezuelan Andes indicate that conditions were wetter in northern South America during the LIA (Polissar et al., 2006b). There is also strong evidence from the southern tropical Andes that the LIA was a period of wetter conditions (Thompson et al., 1986; Bird et al., 2011b; Vuille et al., 2012). The available proxy records therefore indicate that both the northern and southern tropical Andes experienced colder and wetter conditions during much of the LIA. While it is possible that a southward shift in the mean position of the Intertropical Convergence Zone occurred during the LIA (Haug et al., 2001; Sachs et al., 2009), that process alone cannot not explain the spatial pattern of Andean climate change at that time, especially the apparent discord between the Cariaco Basin and Venezuelan Andes. Thus, while gradual changes in insolation forcing clearly influenced climate changes in the Andes during the Holocene, other mechanisms like local responses to changing SSTs operating on millennial and shorter time-scales are needed to explain the observed shifts between synchronous and asynchronous climatic changes in the northern and southern tropical Andes.

\section{Conclusions}

Sediments from lake basins in the Venezuelan Andes record a series of climatic changes in the northern tropics during the Holocene. Previous studies have documented that there was a widespread phase of glacial retreat during the early Holocene that culminated at $\sim 10 \mathrm{ka}$ for valleys with headwalls lower than $\sim 4000 \mathrm{~m}$ asl. The lake sediment records presented here expand these findings and suggest that valleys with headwalls higher than $\sim 4400 \mathrm{~m}$ asl experienced an early Holocene deglacial phase that lasted to between 10.0 and $8.0 \mathrm{ka}$. There is also evidence that conditions were considerably drier from $\sim 8.0$ to $7.7 \mathrm{ka}$ in the Venezuelan Andes, at a time the Montos and Los Anteojos watersheds were mostly ice free. There is evidence of an ice advance in the Mucubaji watershed during the first part of the middle Holocene based on elevated clastic sediment input that is not apparent in other lake sediment records from the region, but coincides with colder conditions in the tropical Atlantic. Another pronounced period of aridity is centered on $\sim 6.0 \mathrm{ka}$ and is most apparent in the Montos record. This dry phase is consistent with other lake level studies in the region. Most of the late Holocene, including the MCA, was characterized by overall warmer and wetter regional conditions as lake sediment records suggest ice retreated. There is strong evidence of glacial advances during the LIA in the Venezuelan Andes at locations with headwalls above $\sim 4600 \mathrm{~m}$ asl, providing additional evidence that it was both colder and wetter at this time. The Holocene glacial and lake level records from Venezuela do not clearly conform to the expected responses to local solar insolation forcing, suggesting additional factors, such as shifting oceanic mean-state 
temperatures were instrumental in driving the pattern of observed climate changes.

\section{Acknowledgments}

We thank Dorfe Diaz, Jaime Escobar, Matthew Finkenbinder, Bryan Friedrichs, Bryan Mark and David Pompeani for their assistance. This project was supported by the National Science Foundation, Paleo-Perspectives on Climate Change program (EAR1003780), Earth System History program (ATM-9809472), and Atmospheric and Geospace Sciences Postdoctoral Research program (AGS-1137750). Additional funding was provided by the Ohio State University Climate Water and Carbon Program, the University of Pittsburgh Center for Latin American Studies, the Geological Society of America, and the Department of Geology and Planetary Science at the University of Pittsburgh.

\section{References}

Abbott, M.B., Seltzer, G.O., Kelts, K.R., Southon, J., 1997. Holocene paleohydrology of the tropical Andes from lake records. Quat. Res. 47, 70-80.

Abbott, M.B., Stafford, T.W., 1996. Radiocarbon geochemistry of modern and ancient Arctic Lake systems, Baffin Island, Canada. Quat. Res. 45, 300-311.

Abbott, M.B., Wolfe, B.B., Wolfe, A.P., Seltzer, G.O., Aravena, R., Mark, B.G., Polissar, P.J., Rodbell, D.T., Rowe, H.D., Vuille, M., 2003. Holocene paleohydrology and glacial history of the central Andes using multiproxy lake sediment studies. Palaeogeogr. Palaeoclimatol. Palaeoecol. 194, 123-128.

Audemard, F.A., 1997. Holocene and historical earthquakes on the Boconó fault system, southern Venezuelan Andes: Trench confirmation. J. Geodyn. 24, 155167.

Audemard, F.A., Pantosti, D., Machette, M., Costa, C., Okumura, K., Cowan, H., Diederix, H., Ferrer, C., 1999. Trench investigation along the Mérida section of the Boconó fault (central Venezuelan Andes), Venezuela. Tectonophysics 308, $1-21$.

Azocar, A., Monasterio, M., 1980. Caracterización Ecológica del Clima en El Páramo de Mucubají. In: Monasterio, M. (Ed.), Estudios Ecologicos en los Páramos Andinos. Ediciones de la Universidad de Los Andes, Merida, Venezuela, pp. 207-223.

Baker, P.A., Seltzer, G., Fritz, S., Dunbar, R.B., Grove, M.J., Tapia, P.M., Cross, S.L., Rowe, H.D., Broda, J.P., 2001. The history of South American tropical precipitation for the past 25,000 years. Science 291, 640-643.

Berg, A., Suchi, S., 2001. La Vegetacion de los Paramos La Aguada, La Fria y Espejo en los Andes Venezolanos. Plantula 3, 47-64.

Berger, A., Loutre, M.F., 1991. Insolation values for the climate of the last 10 million years. Quat. Sci. Rev. 10, 297-317.

Bird, B.W., Abbott, M.B., Rodbell, D.T., Vuille, M., 2011a. Holocene tropical South American hydroclimate revealed from a decadally resolved lake sediment d180 record. Earth Planet. Sci. Lett. 310, 192-202.

Bird, B.W., Abbott, M.B., Vuille, M., Rodbell, D.T., Stansell, N.D., Rosenmeier, M.F., 2011b. A 2300-year-long annually resolved record of the South American summer monsoon from the Peruvian Andes. Proc. Natl. Acad. Sci. 108, 85838588.

Bradbury, J.P., Leyden, B., Salgado-Labouriau, M., Lewis Jr., W.M., Schubert, C., Binford, M.W., Frey, D.G., Whitehead, D.R., Weibezahn, F.H., 1981. Late Quaternary environmental history of Lake Valencia, Venezuela. Science 214, 12991305.

Bradley, R., Yuretich, R., Weingarten, B., 1991. Studies of modern climate. In: Yuretich, R. (Ed.), Late Quaternary Climatic Fluctuations of the Venezuelan Andes. University of Massachusetts, Amherst, MA, pp. 45-62.

Bradley, R.S., Keimig, F., Diaz, H.F., Hardy, D.R., 2009. Recent changes in freezing level heights in the tropics with implications for the deglacierization of high mountain regions. Geophys. Res. Lett. 36.

Braun, C., Bezada, M., 2013. The history and disappearance of glaciers in Venezuela. J. Lat. Am. Geogr. 12, 85-124.

Bronk Ramsey, C., 2008. Deposition models for chronological records. Quat. Sci. Rev. 27, 42-60.

Brown, E.T., Johnson, T.C., Scholz, C.A., Cohen, A.S., King, J.W., 2007. Abrupt change in tropical African climate linked to the bipolar seesaw over the past 55,000 years. Geophys. Res. Lett. 34, L20702.

Carcaillet, J., Angel, I., Carrillo, E., Audemard, F.A., Beck, C., 2013. Timing of the last deglaciation in the Sierra Nevada of the Mérida Andes, Venezuela. Quat. Res. 80 (3), 482-494.

Carrillo, E., Beck, C., Audemard, F.A., Moreno, E., Ollarves, R., 2008. Disentangling Late Quaternary climatic and seismo-tectonic controls on Lake Mucubají sedimentation (Mérida Andes, Venezuela). Palaeogeogr. Palaeoclimatol. Palaeoecol. 259, 284-300.

Clement, A.C., Seager, R., Cane, M., 2000. Suppression of El Niño during the midHolocene by changes in the Earth's orbit. Paleoceanography 15, 731-737.
Cobb, K.M., Westphal, N., Sayani, H.R., Watson, J.T., Di Lorenzo, E., Cheng, H., Edwards, R.L., Charles, C.D., 2013. Highly variable El Niño-Southern oscillation throughout the Holocene. Science 339, 67-70.

Conley, D.J., 1998. An interlaboratory comparison for the measurement of biogenic silica in sediments. Mar. Chem. 63, 39-48.

Croudace, I.W., Rindby, A., Rothwell, R.G., 2006. ITRAX: description and evaluation of a new multi-function X-ray core scanner. In: Geological Society, London, Special Publications, vol. 267, pp. 51-63.

Curtis, J.H., Brenner, M., Hodell, D.A., 1999. Climate change in the Lake Valencia Basin, Venezuela, approximately 12,500 yr BP to present. Holocene 9, 609619.

Curtis, J.H., Hodell, D.A., 1993. An isotopic and trace element study of ostracods from Lake Miragoane, Haiti: a 10,500 year record of paleosalinity and paleotemperature change in the Caribbean. In: Swart, P.K., Lohmann, K.C., McKenzie, J., Savin, S. (Eds.), Climate Change in Continental Isotopic Records. American Geophysical Union, Washington, D.C., pp. 135-152.

Dean Jr., W.E., 1974. Determination of carbonate and organic matter in calcareous sediments and sedimentary rocks by loss on ignition: comparison with other methods. J. Sediment. Petrol. 44, 242-248.

DeMaster, D.J., 1979. The Marine Budgets of Silica and 32-Si. Yale University, New Haven.

DeMaster, D.J., 1981. The supply and accumulation of silica in the marine environment. Geochim. Cosmochim. Acta 45, 1715-1732.

Garreaud, R.D., Vuille, M., Compagnucci, R., Marengo, J., 2009. Present-day South American climate. Palaeogeogr. Palaeoclimatol. Palaeoecol. 281, 180-195.

Hackley, P.C., Urbani, F., Karlsen, A.W., Garrity, C.P., 2005. Geologic Shaded Relief Map of Venezuela. USGS Open-File Report 2005-1038.

Harbor, J.O.N., Warburton, J., 1992. Glaciation and denudation rates. Nature 356, 751

Haug, G.H., Hughen, K.A., Sigman, D.M., Peterson, L.C., Röhl, U., 2001. Southward migration of the intertropical convergence zone through the Holocene. Science 293, 1304-1308.

Hodell, D.A., Brenner, M., Curtis, J.H., Medina-Gonzalez, R., Ildefonso-Chan Can, E., Albornaz-Pat, A., Guilderson, T.P., 2005. Climate change on the Yucutan Peninsula during the Little Ice Age. Quat. Res. 63, 109-121.

Hodell, D.A., Curtis, J.H., Jones, G.A., Higuera-Gundy, A., Brenner, M., Binford, M.W., Dorsey, K.T., 1991. Reconstruction of Caribbean climate change over the past 10,500 years. Nature 352,790 .

Jahn, A., 1925. Observaciones glaciologicas en los Andes Venezolanos. Cult. Venez. 64, 265-280.

Kaser, G., Osmaston, H., 2002. Tropical Glaciers. Cambridge University Press, Cambridge.

Kelly, M.A., Lowell, T.V., Applegate, P.J., Phillips, F.M., Schaefer, J.M., Smith, C.A. Kim, H., Leonard, K.C., Hudson, A.M., 2014. A locally calibrated, Lateglacial 10Be production rate from a low-latitude, high-altitude site in the Peruvian Andes. Quat. Geochronol. (in press).

Koch, J., Clague, J.J., 2006. Are insolation and sunspot activity the primary drivers of glacier fluctuations? PAGES News 14, 20-21.

Koutavas, A., deMenocal, P.B., Olive, G.C., Lynch-Stieglitz, J., 2006. Mid-Holocene El Niño-Southern Oscillation (ENSO) attenuation revealed by individual foraminifera in eastern tropical Pacific sediments. Geology 34, 993-996.

Mahaney, W.C., Dirszowsky, R.W., Kalm, V., 2007. Comment: Late Quaternary deglacial history of the Mérida Andes, Venezuela. N. D. Stansell, M. B. Abbott, P. J. Polissar, A. P. Wolfe, M. Bezada and V. Rull (2005) Journal of Quaternary Science 20: 801-812. J. Quat. Sci. 22, 817-821.

Monasterio, M., Reyes, S., 1980. Diversidad ambiental y variacion de la vegetacion en los páramos de los Andes Venezolanos. In: Monasterio, M. (Ed.), Estudios Ecologicos en los Páramos Andinos. Ediciones de la Universidad de Los Andes Merida, Venezuela, pp. 47-91.

Nussbaumer, S.U., Steinhilber, F., Trachsel, M., Breitenmoser, P., Beer, J., Blass, A. Grosjean, M., Hafner, A., Holzhauser, H., Wanner, H., Zumbühl, H.J., 2011. Alpine climate during the Holocene: a comparison between records of glaciers, lake sediments and solar activity. J. Quat. Sci. 26, 703-713.

Polissar, P.J., 2005. Lake records of Holocene climate change. In: Geosciences. University of Massachusetts, Cordillera de Mérida, Venezuela.

Polissar, P.J., Abbott, M.B., Shemesh, A., Wolfe, A.P., Bradley, R.S., 2006a. Holocene hydrologic balance of tropical South America from oxygen isotopes of lake sediment opal, Venezuelan Andes. Earth Planet. Sci. Lett. 242, 375.

Polissar, P.J., Abbott, M.B., Wolfe, A.P., Bezada, M., Rull, V., Bradley, R.S., 2006b. Solar modulation of Little Ice Age climate in the tropical Andes. Proc. Natl. Acad. Sci. 103, 8937-8942.

Polissar, P.J., Abbott, M.B., Wolfe, A.P., Vuille, M., Bezada, M., 2013. Synchronous interhemispheric Holocene climate trends in the tropical Andes. Proc. Natl. Acad. Sci. 110, 14551-14556. http://dx.doi.org/10.1073/pnas.1219681110.

Pulwarty, R.S., Barry, R.G., Riehl, H., 1992. Annual and seasonal patterns of rainfall variability over Venezeula. Erdkunde 46, 273-289.

Reimer, P.J., Baillie, M.G.L., Bard, E., Bayliss, A., Beck, J.W., Blackwell, P.G., Bronk Ramsey, C., Buck, C.E., Burr, G.S., Edwards, R.L., Friedrich, M., Grootes, P.M. Guilderson, T.P., Hajdas, I., Heaton, T.J., Hogg, A.G., Hughen, K.A., Kaiser, K.F., Kromer, B., McCormac, G., Reimer, R.W., Richards, D.A., Southon, J.R., Talamo, S., Turney, C.S.M., van der Plicht, J., Weyhenmeyer, C., 2009. IntCal09 and Marine09 radiocarbon age calibration curves, 0-50,000 years cal BP. Radiocarbon 51, $1111-1150$.

Rodbell, D.T., Seltzer, G.O., Mark, B.G., Smith, J.A., Abbott, M.B., 2008. Clastic sediment flux to tropical Andean lakes: records of glaciation and soil erosion. Quat. Sci. Rev. 27, 1612-1626. 
Rull, V., Abbott, M.B., Polissar, P.J., Wolfe, A.P., Bezada, M., Bradley, R.S., 2005. 15,000yr pollen record of vegetation change in the high altitude tropical Andes at Laguna Verde Alta, Venezuela. Quat. Res. 64, 308-317.

Rull, V., Stansell, N.D., Montoya, E., Bezada, M., Abbott, M.B., 2010. Palynological signal of the Younger Dryas in the tropical Venezuelan Andes. Quat. Sci. Rev. 29, 3045-3056.

Sachs, J.P., Sachse, D., Smittenberg, R.H., Zhang, Z., Battisti, D.S., Golubic, S., 2009 Southward movement of the Pacific intertropical convergence zone AD 1400 1850. Nat. Geosci. 2, 519-525.

Salgado-Labouriau, M.L., 1986. Late Quaternary paleoecology of Venezuelan high mountains. In: Vuilleumier, F., Monasterio, M. (Eds.), High Altitude Tropical Biogeography. Oxford University Press, New York.

Salgado-Labouriau, M.L., Bradley, R.S., Yuretich, R., Weingarten, B., 1992. Paleoecological analysis of the sediments of Lake Mucubaji, Venezuelan Andes. J. Biogeogr. 19, 317-327.

Schmidt, M.W. Chang, P., Hertzberg, J.E., Them, T.R., Ji, L., Otto-Bliesner, B.L. 2012. Impact of abrupt deglacial climate change on tropical Atlantic subsurface temperatures. Proc. Natl. Acad. Sci. 109, 14348-14352.

Schubert, C., 1972. Geomorphology and glacier retreat in the Pico Bolivar area, Sierra Nevada de Merida, Venezuela. Z. Gletsch. Glazialgeol. VIII, 189-202.

Schubert, C., 1984. The Pleistocene and recent extent of the glaciers of the Sierra Nevada de Merida, Venezuela. Erdwiss. Forsch. 18, 269-278.

Schubert, C., 1987. La Extension de los Glaciares Pleistocenes en la Sierra Nevada de Merida. Bol. Soc. Venez. Cienc. Nat. 41, 299-308.

Schubert, C., 1992. The Glaciers of the Sierra nevada de Merida (Venezuela): a Photographic Comparison of Recent Deglaciation. Erdkunde 46, 58-64.

Schubert, C., 1998. Glaciers of Venezuela, Glaciers of South America. USGS Professional Paper 1386-I.

Schubert, C., Sifontes, R.S., 1970. Boconó fault, Venezuelan Andes: evidence of Postglacial movement. Science 170, 66-69.

Seltzer, G.O., Rodbell, D.T., Burns, S., 2000. Isotopic evidence for late Quaternary climatic change in tropical South America. Geology 28, 35-38.

Sklar, L.S., Dietrich, W.E., 2001. Sediment and rock strength controls on river incision into bedrock. Geology 29, 1087-1090.

Smith, N.D., Ashley, G.M., 1985. Proglacial lacustrine environment. In: Smith, N.D. Ashley, G.M. (Eds.), Glacial Sedimentary Environments.

Stansell, N.D., 2009. Rapid Climate Change in the Tropical Americas during the LateGlacial interval and the Holocene (unpublished PhD dissertation). University of Pittsburgh.
Stansell, N.D., Abbott, M.B., Polissar, P.J., Wolfe, A.P., Bezada, M., Rull, V., 2005. Late Quaternary deglacial history of the Mérida Andes, Venezuela. J. Quat. Sci. 20, 801-812 doi: 810.1002/jqs.1973.

Stansell, N.D., Abbott, M.B., Polissar, P.J., Wolfe, A.P., Bezada, M., Rull, V., 2007a. Reply: Late Quaternary deglacial history of the Mérida Andes, Venezuela: response to comment. J. Quat. Sci. 22, 823-825.

Stansell, N.D., Abbott, M.B., Rull, V., Rodbell, D.T., Bezada, M., Montoya, E., 2010. Abrupt Younger Dryas cooling in the northern tropics recorded in lake sediments from the Venezuelan Andes. Earth Planet. Sci. Lett. 293, 154163.

Stansell, N.D., Polissar, P.J., Abbott, M.B., 2007b. Last Glacial maximum equilibriumline altitude and paleo-temperature reconstructions for the Cordillera de Mérida, Venezuelan Andes. Quat. Res. 67, 115-127.

Stansell, N.D., Rodbell, D.T., Abbott, M.B., Mark, B.G., 2013a. Proglacial lake sediment records of Holocene climate change in the western Cordillera of Peru. Quat. Sci. Rev. 70, 1-14.

Stansell, N.D., Steinman, B.A., Abbott, M.B., Rubinov, M., Roman-Lacayo, M., 2013b. Lacustrine stable isotope record of precipitation changes in Nicaragua during the Little Ice Age and medieval climate anomaly. Geology 41, 151-154.

Thompson, L.G., Mosley-Thompson, E., Dansgaard, W., Grootes, P.M., 1986. The Little Ice Age as recorded in the stratigraphy of the tropical Quelccaya ice cap. Science 234, 361-364.

Tudhope, A.W., Chilcott, C.P., McCulloch, M.T., Cook, E.R., Chappell, J., Ellam, R.M., Lea, D.W., Lough, J.M., Shimmield, G.B., 2001. Variability in the El Niño-Southern oscillation through a Glacial-Interglacial cycle. Science 291, 1511-1517.

Vuille, M., Bradley, R.S., Keimig, F., 2000. Climate variability in the Andes of Ecuador and its relation to tropical pacific and Atlantic Sea surface temperature anomalies. J. Clim. 13, 2520-2535.

Vuille, M., Burns, S.J., Taylor, B.L., Cruz, F.W., Bird, B.W., Abbott, M.B., Kanner, L.C., Cheng, H., Novello, V.F., 2012. A review of the South America monsoon history as recorded in stable isotope proxies over the past two millennia. Clim. Past 8 , 1309-1321.

Vuille, M., Kaser, G., Juen, I., 2008. Glacier mass balance variability in the Cordillera Blanca, Peru and its relationship with climate and the large-scale circulation. Glob. Planet. Change 62, 14-28.

Wesnousky, S.G., Aranguren, R., Rengifo, M., Owen, L.A., Caffee, M.W., Murari, M.K., Perez, O.J., 2012. Toward quantifying geomorphic rates of crustal displacement, landscape development, and the age of glaciation in the Venezuelan Andes. Geomorphology 141-142, 99-113. 